\title{
Sunlight-induced growth delay of planktonic marine bacteria in filtered seawater
}

\author{
Michael E. Sieracki* \& John McN. Sieburth \\ Graduate School of Oceanography, University of Rhode Island, Narragansett, Rhode Island 02882, USA
}

\begin{abstract}
The growth of natural populations of planktonic marine bacteria was observed upon exposure to natural sunbight. In Narragansett Bay seawater, with most of the phototrophic and bacteriagrazing nanoflagellates removed by filtration, a slight increase in bacterial populations began after 24 to $36 \mathrm{~h}$ in the dark. In populations exposed to sunlight, growth was delayed further. Diluting the bacteria-dominated size fraction $(<0.6 \mu \mathrm{m})$ with $0.2 \mu \mathrm{m}$ filtered seawater resulted in a shorter lag period and more rapid growth than undiluted filtrates. Sunlight caused a significant lengthening of the lag period but did not affect the exponential growth rate suggesting that the bacteria were susceptible to sunlight while undergoing protein synthesis prior to exponential growth. Use of spectral filters indicated that the growth delay was primarily due to UV-A wavelengths $(320$ to $400 \mathrm{~nm})$. These results are analogous to sunlight effects on bacteria observed in pure culture experiments. Use of neutral density filters indicated that the effect was pronounced at 50 and $25 \%$ of surface sunlight and detectable at $16 \%$. Photoinhibition of bacterial activities could be a significant factor in the diel cycling of organic matter, nutrients and reactive gases in the euphotic zone of the oceans.
\end{abstract}

\section{INTRODUCTION}

The diel cycling of dissolved organic matter (DOM) between phytoplankton and bacteria in the marine enviroment has been explored by a number of investigators (Sieburth et al. 1977, Burney et al. 1979, Meyer-Reil et al. 1979, Straskrabova \& Fuksa 1982, Krambeck 1984). Burney et al. $(1981,1982)$ have shown that a build-up of dissolved polysaccharides often occurs during the afternoon in a variety of marine environments. A concurrent daytime decrease in bacterial abundance has been noted in both open ocean (Burney et al. 1982, Johnson et al. 1983) and near-shore waters (Ferguson \& Palumbo 1979, Krambeck 1984). A similar afternoon decline of bacteria has been repeatedly observed in the upper layer of a mesocosm tank simulating a stratified estuarine system (Sieracki \& Sieburth 1985). A sunlight-induced inhibition of bacteria, including those capable of utilizing these carbohydrates, could be one explanation why the afternoon release of organic matter is not immediately taken up by bacteria (Burney 1986).

\footnotetext{
- Present address: College of William and Mary, School of Marine Science, Virginia Institute of Marine Science, Gloucester Point, Virginia 23062, USA
}

The detrimental effects of UV radiation on biological systems have been well documented (Gates 1928, Smith 1977). Perhaps less well known, however, are the effects on bacteria of the longer wavelength UV-B (280 to $350 \mathrm{~nm}$ ) and near-UV visible light (up to $490 \mathrm{~nm}$ ), first reported by Hollaender (1943). A variety of bacterial processes have since been shown to be affected by these wavelengths; these include both nitrite and ammonia oxidation (Müller-Neuglück \& Engel 1961, Hooper \& Terry 1974), growth of Escherichia coli (Jagger 1975), and bacterial membrane function (Moss \& Smith 1981). Such information on the biological effects of light of these wavelengths has led to investigations into their ecological effects (Calkins 1975, Worrest et al. 1978, Calkins \& Thordardottir 1980). Naturally occurring sunlight has been implicated as a significant factor in the decline of coliform bacteria in seawater (Gameson \& Saxon 1967 , Chamberlin \& Mitchell 1978, Fujioka et al. 1981, Lessard \& Sieburth 1983). The fact that nitrite oxidation is more sensitive to low light levels than ammonia oxidation prompted Olson (1981) to propose that differential photoinhibition may be the cause of the widespread marine nitrite maximum found near the $1 \%$ light depth.

Early investigators, including Fischer (1894) and 
Schmidt-Nielsen (1901), attributed the diel and vertical distributions of culturable marine bacteria to detrimental sunlight effects. ZoBell \& McEwen (1935) discounted this, reporting that the lethal effect of sunlight did not extend below $20 \mathrm{~cm}$ in seawater. Their cultural procedures, however, would not have been suitable for detecting growth delay and inhibition in the much larger, non-culturable, natural population.

Few recent studies have been conducted on the effect of sunlight on natural marine bacterial populations. Sieburth (1968a) reported an increase in pigmented bacteria with seasonal increases in solar intensity. Thomson et al. (1980) used artificial light in long term $(3$ to $6 \mathrm{wk}$ ) microcosm experiments to examine the impact of enhanced UV-B radiation on estuarine bacteria. Supplemental UV radiation decreased the number of culturable bacteria, and increased both the proportion of pigmented colony-formers and ${ }^{14} \mathrm{C}$-glutamate respiration. It is difficult, however, to relate UV dose rates from an artificial source back to natural sunlight (N.A.S. 1979). Narrow spikes of UV occurred in the reported spectra of even the 'UV-deficient' condition (Thomson et al. 1980). Bailey et al. (1983) showed that short exposures to natural sunlight inhibit amino acid uptake by estuarine bacteria. The effect was most pronounced under intense summer sunlight, and was attributed to UV-B and longer wavelengths. These 2 studies involved un-fractionated seawater samples which would include significant populations of both phototrophic and bacterivorous protists in addition to bacteria (Davis et al. 1985).

The effect of sunlight on the bacterial populations in natural, sunlit surface waters could be either masked or enhanced by the presence of other trophic levels since these can influence bacteria through substrate production, nutrient regeneration, and predation. To reduce such complicating trophic interactions, we have studied the direct effect of natural sunlight on the bacteria-dominated fraction of seawater. By passing the seawater through a $0.6 \mu \mathrm{m}$ porosity Nuclepore filter, the eucaryote population is significantly reduced (Fuhrman \& McManus 1984, Cynar et al. 1985a). We have studied changes in the natural, mixed bacterial population, both undiluted and diluted, under natural sunlight and in the dark. Sunlight intensities down to $16 \%$ of surface irradiance caused a distinct growth delay in mixed, natural populations. This growth delay is primarily due to the longer wavelengths in the UV-A (320 to $400 \mathrm{~nm}$ ) range.

\section{MATERIALS AND METHODS}

Ambient population experiments. Narragansett Bay seawater (NBW) was collected immediately before each experiment in sterile bottles from the Narragansett Bay Campus pier (Rhode Island, USA) near high tide. For non-diluted population experiments, NBW was aseptically filtered through a $0.6 \mu \mathrm{m}$ Nuclepore filter (Nuclepore Corp., Pleasanton, California) to yield seawater with essentially the bacterial population, but with greatly reduced populations of protists. This water was then placed in replicate 11 Pyrex flasks or Teflon FEP bottles (Nalge Co., Rochester, New York). For the dark controls, either black Teflon bottles were used or clear Pyrex flasks were wrapped with aluminium foil and black plastic film. All bottles were incubated completely submersed in a large outdoor water bath which maintained in situ temperatures.

In all experiments ambient surface sunlight was measured using a quantum meter (Li-Cor, Inc., Lincoln, Nebraska) over the visible spectrum (400 to $700 \mathrm{~nm}$ ). The instantaneous data was either integrated automatically with a printing integrator, or manually from strip chart recordings using a planimeter.

Reduced population experiments. In these experiments the bacterial population was diluted by $1 / 100$ in essentially bacteria-free NBW to reduce competition for ambient nutrients and allow 'space' for growth. NBW was sequentially filtered, with sterile filtration apparatus, through a Gelman (Type A/E) glass fiber filter, a $0.45 \mu \mathrm{m}$ Millipore filter and finally through a $0.2 \mu \mathrm{m}$ Nuclepore filter to yield bacteria-reduced NBW (BR-NBW). This filtration resulted in a $1 / 1000$ reduction in bacteria, with less than 1000 very small bacteria per $\mathrm{ml}$ in the BR-NBW, based on direct microscope counts. Vacuum was maintained below $20 \mathrm{~cm} \mathrm{Hg}$ at all times. A subsample of the Gelman A/E filtrate was passed through a $0.6 \mu \mathrm{m}$ Nuclepore filter to yield an inoculum containing primarily the free, planktonic bacterial cells. This size fraction typically contained over $90 \%$ of the total bacterial population. Total dissolved organic carbon (DOC) determinations obtained with an Oceanography International total carbon system (model 524B) indicated no detectable DOC increase due to any of the filtration steps.

The remaining steps were conducted under sterile conditions in a laminar flow hood. Inoculum was added to the BR-NBW at a $1 \%(\mathrm{v} / \mathrm{v})$ dilution to yeld an initial bacterial concentration approximately 2 logs below the natural population. Inoculated BR-NBW was mixed with a magnetic stirrer for 10 to $15 \mathrm{~min}$, and then dispensed into replicate, acid-cleaned, clear or black $250 \mathrm{ml}$ Teflon bottles. In several experiments, control bottles containing only un-inoculated BR-NBW were incubated to determine if growth of any bacteria passing the $0.2 \mu \mathrm{m}$ filter could be detected. All bottles were incubated in a large, shallow outdoor water bath that was oriented to prevent shading and maintained at in situ temperatures within $\pm 1 \mathrm{C}^{\circ}$. They were 
clamped 2 to $3 \mathrm{~cm}$ below the water surface at an angle approximately perpendicular to the noon sun to maximize sunlight exposure. The bottles were shaken and sampled every 3 to $6 \mathrm{~h}$. Bottles were never depleted by more than $50 \%$ over the course of an experiment. Samples were preserved with either glutaraldehyde or formalin ( $1 \%$ final, $v / v)$.

Sunlight spectrum and intensity. Experiments were conducted to determine the effects of various portions of the solar spectrum and various sunlight intensities on the growth of natural bacterial populations. The spectral filters employed were Tuffak polycarbonate (0.5 mm, Rohm \& Haas, Inc.) and Mylar polyester film $(0.1 \mathrm{~mm})$. The spectral transmittance of these materials, and clear Teflon, was measured in a Carey model 17 recording spectrophotometer from 250 to $450 \mathrm{~nm}$; the resulting curves were identical to those reported by Jokiel \& York (1984) for these materials. The polycarbonate filters blocked wavelengths less than $400 \mathrm{~nm}$, while transmitting more than $85 \%$ over the visible spectrum. The polyester filters blocked below about $320 \mathrm{~nm}$, and transmitted $85 \%$ or more of the UV-A and visible wavelengths. To examine the effect of reduced sunlight intensities, layers of window screen were used as neutral density filters. Light intensities passing the screens were measured with a quantum light meter (Li-Cor, Inc.) over the visible spectrum ( 400 to $700 \mathrm{~nm}$ ). Only single bottles were incubated at the 16 and $100 \%$ light levels. Both the spectral and neutral density filters were wrapped around the clear Teflon bottles used in these experiments. The spectral transmittance of clear Teflon exceeds $80 \%$ at all wavelengths longer than $280 \mathrm{~nm}$

Bacterial counts. Bacteria were enumerated using the epifluorescence direct count method (Hobbie et al. 1977) with the fluorochrome 4',6-diamidino-2-phenylindole (DAPI) (Porter \& Feig 1980). Slides were counted on an Olympus BHT-2 epifluorescence microscope either visually (Cynar et al. 1985b) or with an image analysis epifluorescence microscope system (Sieracki et al. 1985).

Lag time calculation. Growth curves resulting from the dilution culture experiments were analyzed graphically to determine the lag time $\left(T_{L}\right)$. The definition of Monod (1949) was used in this calculation:

$$
T_{L}=t_{R}-\frac{\log _{2} X_{R}-\log _{2} X_{0}}{R}
$$

where $\mathrm{R}=$ exponential growth rate; $t_{R}=$ time when the culture reaches a certain density, $X_{R}$, chosen within the exponential phase; $\mathrm{X}_{0}=$ initial cell density. For all calculations the geometric mean of the initial and maximum cell concentrations in a given experiment was used for $\mathrm{X}_{R}$.

\section{RESULTS}

The effect of near-surface intensities of sunlight on ambient populations of Narragansett Bay bacteria, with protists reduced by filtration, is shown for 2 separate experiments in Fig. 1. In both experiments, the populations did not change significantly from initial levels in either the light or dark condition for the first $24 \mathrm{~h}$. In the 10 March experiment (Fig. 1A) the light and dark bottles began diverging during the second daylight period with gradual growth in the dark, and a maximum doubling time of $17 \mathrm{~h}$. The light-exposed population initiated growth approximately 24 h later, with a maximum doubling time of $24 \mathrm{~h}$. This pattern was repeated in the 7 April experiment (Fig. 1B). Again, the bacteria maintained in the dark began growth during the second light period, while growth was inhibited in the light-exposed population. Growth might have occurred in the light condition with a longer observation period.

The results of a typical experiment with the ambient bacterial population diluted by 2 orders of magnitude

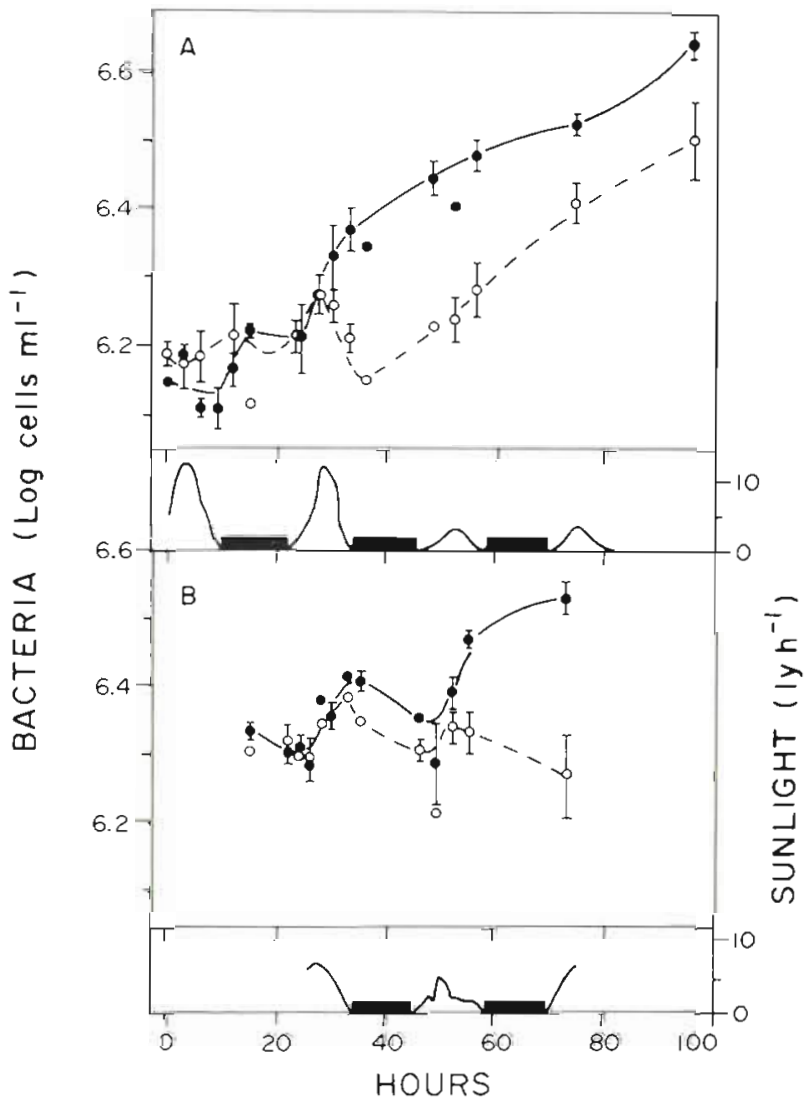

Fig. 1. Effect of sunlight on ambient, natural populations of bacteria in $0.6 \mu \mathrm{m}$ filtrates of Narragansett Bay seawater. (O) Sunlight; (@) dark control. (A) 10 to 13 Mar 1982. (B) 7 to 10 Apr 1982. Dark periods represented by solid bars on time axis. Error bars represent range of 2 replicate bottles. Points without error bars indicate a range smaller than the symbol 
in BR-NBW is shown in Fig. 2. A classical bacterial growth curve, with lag, exponential, and stationary phases, was always observed. Replicate bottles followed each other quite closely, relative to the large increase in cell numbers observed. Compared to the experiments with ambient, undiluted populations (Fig. 1), the lag period was shorter, the growth rate faster, and the overall population increase was nearly 2 logs versus less than half a log for the ambient population. Bacteria in the sunlight-exposed bottles under-

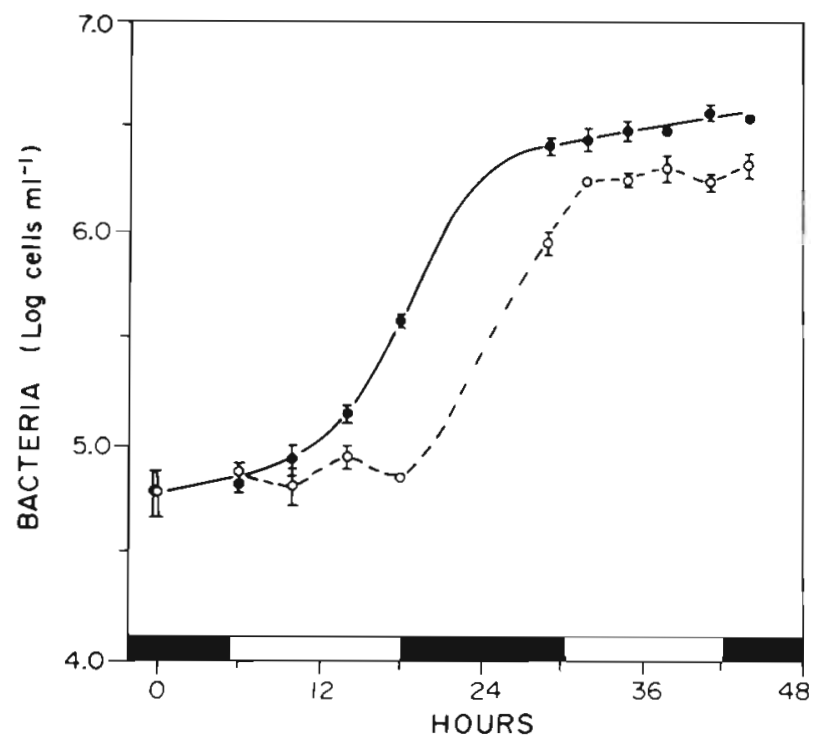

Fig. 2. Typical sunlight-induced growth delay in populations of Narragansett Bay bacteria diluted in filtered, unamended seawater. (O) Sunlight; ( $\bullet$ dark control. Legend as in Fig. 1 went a consistent and significant delay prior to exponential growth compared to the dark control. Control bottles containing un-inoculated BR-NBW were sampled to determine whether the bacteria passing the 0.2 $\mu \mathrm{m}$ filter could grow significantly during the incubations. Detectable growth was observed in only one experiment, but only after $60 \mathrm{~h}$ of incubation, and may have resulted from contamination due to the periodic sampling.

The experimental conditions and growth curve parameters for all the reduced-population growth experiments are summarized in Table 1 . The lag period in the light was consistently longer than in the dark, with means of 26 and $19 \mathrm{~h}$, respectively. This growth delay is attributable to sunlight and ranged from approximately 10 to $100 \%$ (average $=39 \%$ ) longer than the lag in the dark controls. The doubling times attained during exponential growth in the sunlight-exposed flasks were very similar to those in the dark, averaging 2.66 and $2.89 \mathrm{~h}$, respectively. They were not significantly different as tested by the Wilcoxon ranked sum test $(95 \%$ significance level). Lower temperatures caused an increased lag time in both the light and dark, with the longest lag period occurring in the experiment conducted at $12^{\circ} \mathrm{C}$.

The wavelengths of light responsible for the sunlight-induced growth delay were determined from the experiment shown in Fig. 3. The replicate bottles followed each other closely (Fig. 3A). The polycarbonate filter, which transmits visible light but blocks all UV, offered almost complete protection from sunlight. Mylar polyester, which transmits visible and UV-A,

Table 1. Range and mean of sunlight-induced growth delay in reduced, unamended populations of Narragansett Bay bacteria

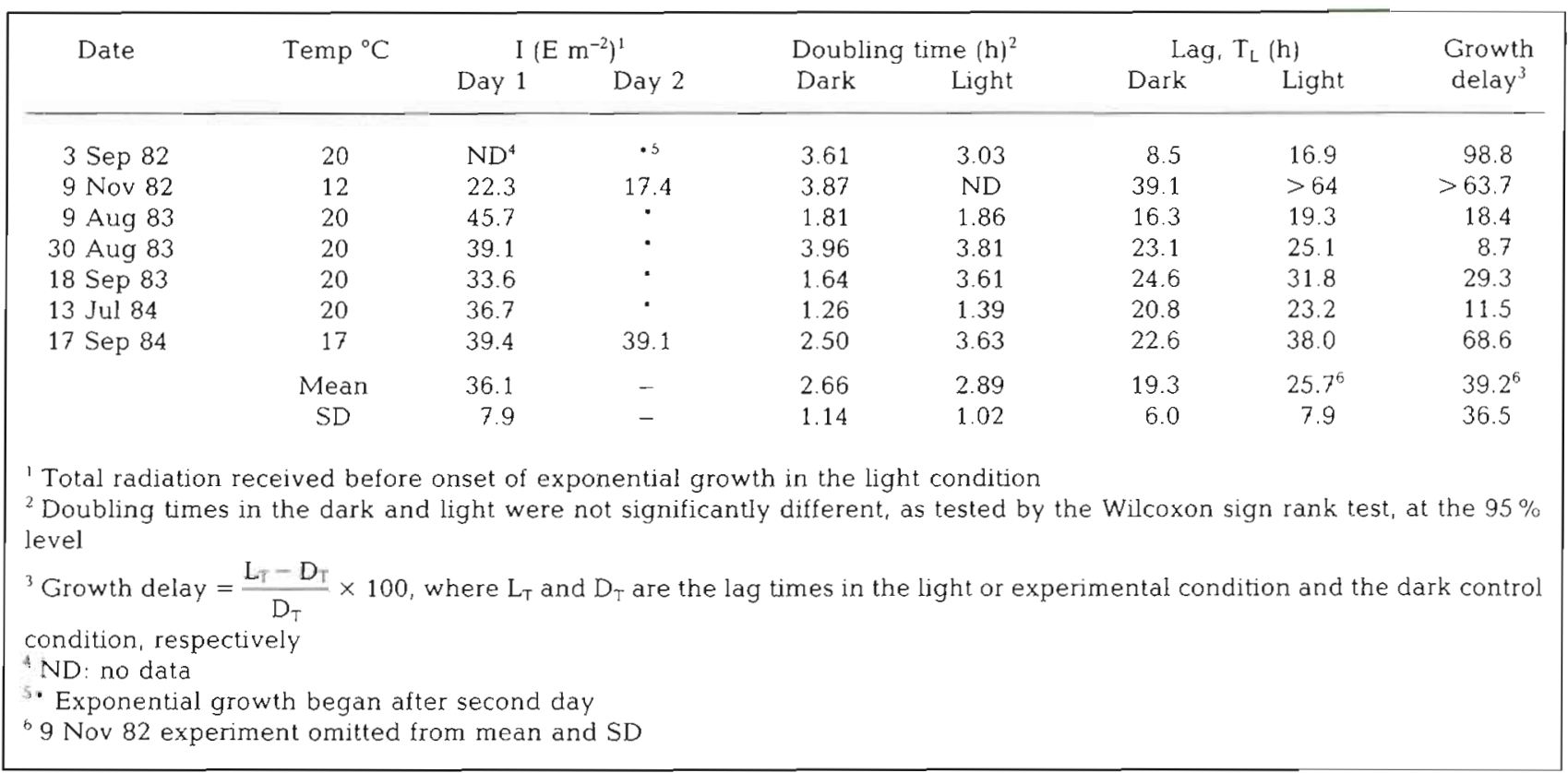



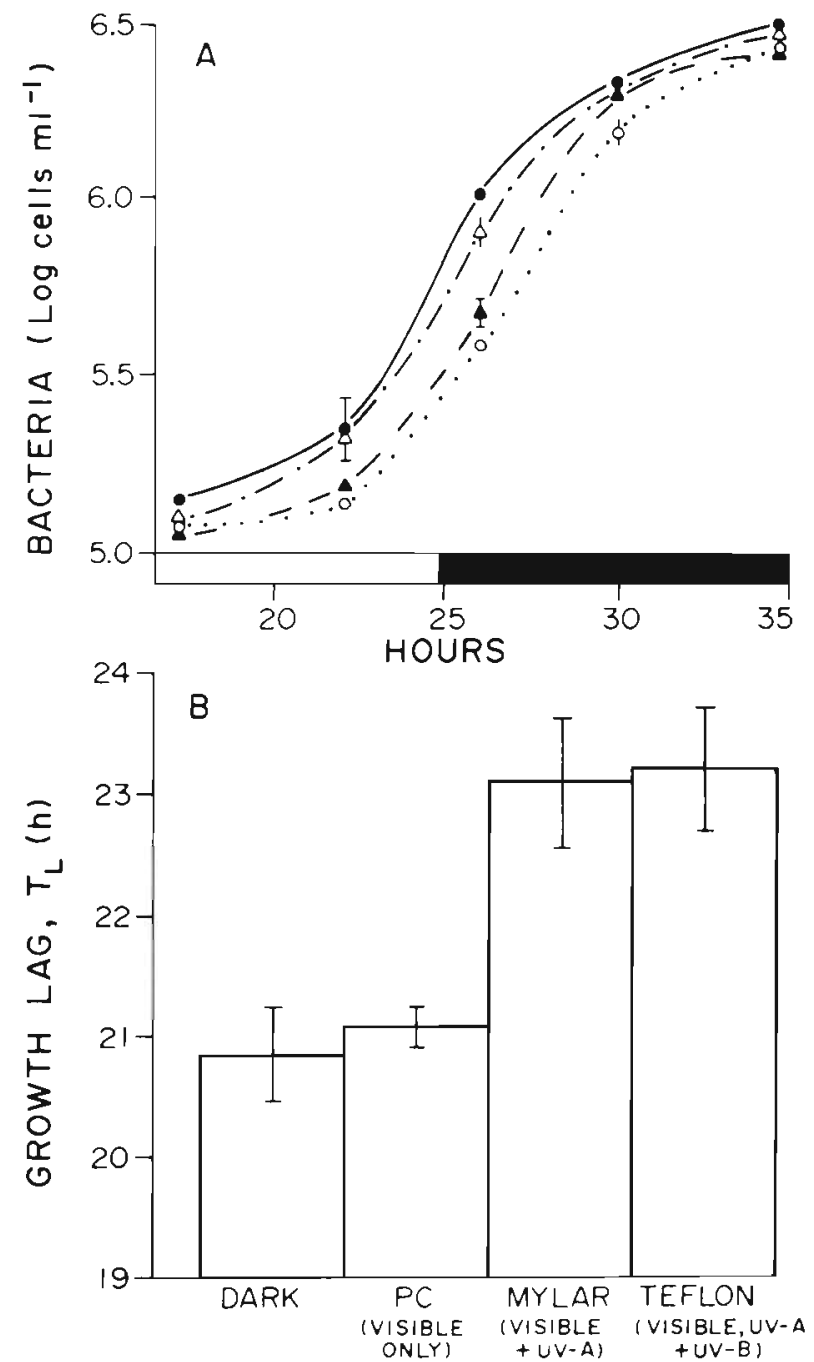

Fig. 3. Effect of long-pass spectral filters on light-induced growth delay. (A) Growth curves of 1:100 diluted, natural bacterial populations in the dark (•), with a polycarbonate filter to block all UV $(\Delta)$, with a mylar polyester filter to block UV-B ( $\Delta)$, and with no spectral filter $(O)$. Dark period indicated by solid bar (B) Growth lag time for each condition showing the importance of UV-A wavelengths in inhibiting growth. PC; polycarbonate. Error bars as in Fig. 1

but blocks UV-B wavelengths, did not protect the bacteria from the sunlight-induced growth delay (Fig. 3B). The lag period under this filter was virtually identical to the Teflon condition which transmits all solar UV wavelengths. This demonstrates that the UV-A wavelengths are primarily responsible for the prolonged lag period due to sunlight.

Attenuation of sunlight intensity, by neutral density filters, diminished the sunlight-induced growth delay (Fig. 4). The calculated growth lag was $22.6 \mathrm{~h}$ in the dark, $24.1 \mathrm{~h}$ at $16 \%, 24.5 \mathrm{~h}$ at $25 \%, 28.8 \mathrm{~h}$ at $50 \%$ and $38.1 \mathrm{~h}$ in full sunlight, indicating that growth inhibition by sunlight was quite distinct at $50 \%$ and $25 \%$ of surface intensity and was still detectable at less than
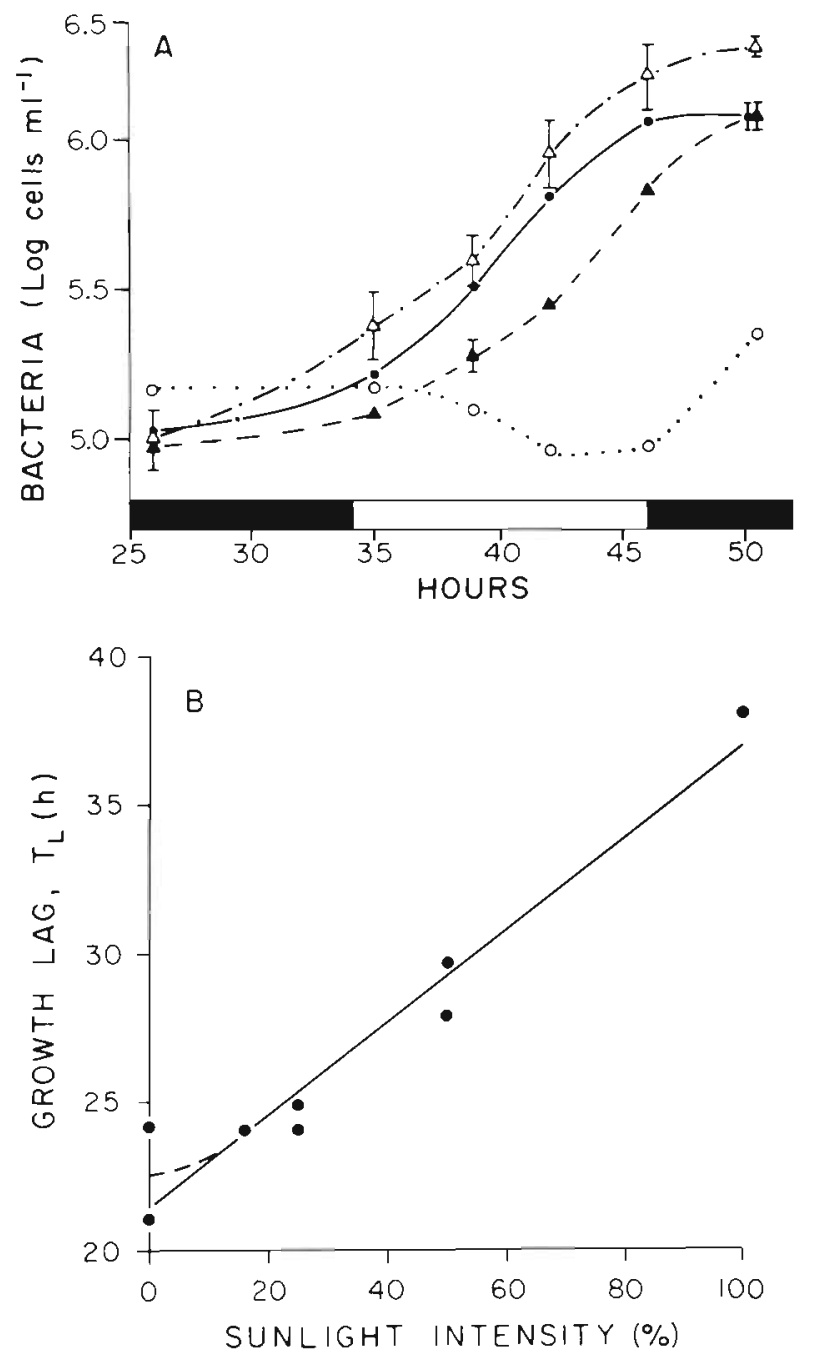

Fig. 4. Effect of sunlight attenuation on light-induced growth delay. (A) Growth curves of diluted, natural bacterial populations in the dark $(\Delta)$, and under $25 \%(\bullet), 50 \%(\Delta)$, or $100 \%$ $(O)$ of surface sunlight. Dark periods indicated by solid bars. (B) Growth lag time as a function of sunlight intensity, showing a detectable growth delay between 16 and $25 \%$ surface sunlight intensity. Single bottles were incubated under 16 and $100 \%$ light levels

$16 \%$ of surface intensity. This appears to be a linear effect (Fit. $4 \mathrm{~B}$ ). Since the maximum growth rate in the full sunlight condition may not have been reached in this experiment (Fig. 4A), the average rate of the other 7 bottles was used for $R$ in the growth lag calculations for all conditions (Fig. 4B).

\section{DISCUSSION}

Recent studies on the effect of sunlight on natural estuarine bacterial populations (Thomson et al. 1980, Bailey et al. 1983) did not take into account the numerous photosynthetic and bacterivorous nanoplankton 
which complicate the interpretation of changes in bacterial populations. In these previous studies, the effects of sunlight on bacteria could not be distinguished from possible trophic effects. An example of such an effect is the production of oxygen by photosynthesis yielding such toxic photooxidation products as the superoxide radical, hydrogen peroxide and organic peroxides (Fridovich 1974, Mill et al. 1980, Zafiriou et al. 1984). Non-specific inhibitors could also be released by actively photosynthesizing or senescent algal cells (Sieburth \& Pratt 1962, Sieburth 1964, 1968b). Additional complications could involve the virtually unknown effects of light on the grazing activity of bacterivorous nanoflagellates and ciliates. This study was designed to remove, or at least reduce, the effects of these protists by selective filtration. In this way, the direct effects of sunlight on natural bacterial populations could be examined and related to the wide body of knowledge concerning such effects on pure bacterial cultures. Filtration through $0.6 \mu \mathrm{m}$ pore filters does not eliminate all autotrophs, since we occasionally observed cyanobacteria in some filtrates by epifluorescence microscopy. Autofluorescent cells were not observed during our incubations, however, even when larger sample volumes were specifically examined for their presence. Similarly, bacterial grazers have been shown to pass this size filter, but in very small numbers, perhaps less than $50 \mathrm{ml}^{-1}$ (Fuhrman \& McManus 1984, Cynar et al. 1985a). A decline in bacteria, indicative of predation, was not observed in our experiments.

Dilution of the natural bacterial population resulted in growth without the prolonged delay observed at ambient bacterial populations (Fig. 1) and allowed the effect of sunlight on growth to be more readily observed (Fig. 2). The lag time was substantially reduced in both the light and dark conditions by dilution. This is probably because the reduced bacterial population is released from resource competition (Kirchman et al. 1982, Sieracki \& Sieburth 1985). Although growth could be due to organic matter released by cells lysed during filtration, Ammerman et al. (1984) concluded that this source was not significant in these types of incubations. Similarly, our measurements of dissolved organic carbon levels at each step in the filtration process revealed no significant increase. We did not observe significant growth of the bacteria capable of passing a $0.2 \mu \mathrm{m}$ Nuclepore filter, in control bottles not inoculated with the larger bacteria. These 'minibacteria' (Watson et al. 1977) we observed from estuarine waters were neither as numerous, nor as active, as those observed by Li \& Dickie (1985) from open ocean waters. They found significant growth and amino acid uptake only after several hours of incubation.
Growth of bacteria on the bottle walls was not determined, but was minimized by the use of Tefion bottles (Dexter et al. 1975). Any wall growth would be expected to decrease the amount of light exposure to the bacteria and therefore would have reduced the observed light effect. Suspended particles were removed by the filtration step in the procedure.

The duration of the sunlight-induced growth delay was related to the light intensity within a given experiment (Fig. 4), but the amount of sunlight received among the different experiments did not correlate with the growth delay (Table 1). This may be due to the fact that UV radiation, especially diffuse irradiance, does not directly correlate with the portion of the spectrum we measured (400 to $700 \mathrm{~nm}$ ). The overall range of measured sunlight intensity across experiments was not very great, whereas the variation in the duration of the lag period was quite wide, ranging from 8.46 to $24.56 \mathrm{~h}$ in the dark bottles of the experiments conducted at $20^{\circ} \mathrm{C}$. This variation in lag time is probably due to a combination of factors, including the seasonal composition of the bacterial community and the nutrient status of the seawater. Changes in the bacterial community are known to occur seasonally due to temperature variation (Sieburth 1967) and phytoplankton blooms (Sieburth 1968b). Changes in water quality also have an effect on phototoxicity (Sieburth \& Pratt 1962). Due to this observed variation in the length of the lag period between experiments, spectral and intensity comparisons were made only within single experiments so that conditions were identical between comparisons.

In addition to selection occurring in incubation experiments due to container effects (Ferguson et al. 1984), selection for a light-resistant population may have occurred in the light condition. Light has been shown to select for pigmented bacteria in Narragansett Bay (Sieburth 1968a) and in microcosm experiments (Thomson et al. 1980). The growth delay could be due to the production of the pigment-synthesizing apparatus, or the protective pigments themselves, in the cells with this capability.

Another possible mechanism for the observed growth delay is the accumulation of a toxic photoproduct. Carbon monoxide is a good candidate since it is known to be produced in seawater by a photoreaction of dissolved organic matter (Wilson et al. 1970). The mechanism may involve the direct photolysis of aldehydes (Zika 1981). CO has been shown to exhibit diel cycles in oceanic surface waters indicating photoperiod production and nocturnal consumption (Conrad et al. 1982). It is a potent respiration inhibitor, blocking the electron transport chain between cytochrome a and oxygen, and may have induced the growth delay in the general bacterial population. CO generation may also 
have selected for a population of chemolithotrophic carboxydobacteria capable of consuming CO (Conrad \& Seiler 1982). Our results could be explained by a sequence of $\mathrm{CO}$ photoproduction, population inhibition, selection for a CO-utilizing population, and subsequent growth of the general population after $\mathrm{CO}$ was reduced.

The observed growth delay may also have been due to a direct effect of sunlight on bacterial cells. Numerous studies demonstrate a remarkably similar photoinduced growth delay caused by near-UV light in laboratory studies on pure cultures of Escherichia coli and other bacteria (Jagger et al. 1964, Eisenstark 1971, Ramabhadran \& Jagger 1975, Kubitschek \& Doyle 1981). In these studies, as in the present study (Fig. 2), the exposure to near-UV light caused a prolonged lag period but did not affect either the exponential growth rate or final cell density. Exposure to natural sunlight for only a few minutes has been reported to cause such a growth delay in E. coli (Jagger 1975). The mechanism for this effect has been shown to involve the partial inactivation of certain tRNA molecules, causing the cell to react in a manner analogous to amino acid starvation (Ramabhadran \& Jagger 1976). The action spectrum for this effect has a peak at about $340 \mathrm{~nm}$ and an approximate width of $40 \mathrm{~nm}$.

This action spectrum falls within the spectral range of the UV-A which we found to be most important in the photo-induced delay of growth. Jagger et al. (1964) found that this portion of the spectrum inhibits Escherichia coli cell division and causes the growth delay. In contrast, Bailey et al. (1983) found that UV-B, UV-A and visible wavelengths all contributed to photoinhibition of labelled amino acid uptake, especially at higher sun angles. This discrepancy could be due to complicating trophodynamic effects discussed above which this study avoided. The fact that these longer UV wavelengths are the primary inhibiting ones is ecologically important, since biologically effective dose-rates of these wavelengths can penetrate seawater to depths on the order of tens of meters (Jerlov 1950, Smith \& Baker 1979).

Although the use of neutral density filters cannot accurately represent light quality in the water column, they can provide an indication of the sensitivity of bacterial populations. Detection of a sunlight effect on the growth of natural, mixed populations even at $16 \%$ of surface intensity means that photoinhibition could be affecting bacterial processes to a depth of $55 \mathrm{~m}$ in clearest ocean water (extinction coefficient, $\mathrm{k}=$ $\left.0.033 \mathrm{~m}^{-1}\right)$ or to $12 \mathrm{~m}$ in clear coastal waters $(\mathrm{k}=0.15$ $\mathrm{m}^{-1}$ ). The acute photosensitivity of the nitrite and ammonia-oxidizing bacteria is an example which has been studied from an ecological perspective (Horrigan et al. 1981, Olson 1981, Ward et al. 1981). An oceanic methane-oxidizing bacterium has also been found to be very light sensitive (Sieburth et al. 1984).

We have shown that sunlight has a direct effect on natural, mixed bacterial populations which is quite similar to the growth delay found in pure culture experiments. This effect is independent of interactions with higher trophic groups in the plankton, since the bacterial population was essentially isolated from them. The sunlight effect on natural populations was found to be detectable even at $16 \%$ of the intensity of surface sunlight, and could therefore be influencing bacterial processes in the upper meters to tens of meters in the sea. The UV-A portion of the spectrum was most important in causing the growth delay and neither shorter UV-B nor longer visible wavelengths contributed significantly to the growth delay. These findings suggest that further study of the mechanism of growth delay is necessary to determine whether direct or indirect effects are dominant. Recent work (Sieracki \& Sieburth 1985) has indicated that midday sunlight in temperate latitudes can affect bacteria abundances in whole-water populations over short time periods. The sunlight-induced growth delay of marine bacteria appears to be one of the controlling factors in the diel cycling of organic matter which allows DOM to build up during the light period by temporally decoupling the link between photosynthetic production and bacterial utilization.

Acknowledgements. We thank Paul W. Johnson for help with microscopy and reviewing the manuscript, Kenneth M. Johnson for assistance in analyzing the DOC samples, and Marjorie McCray for general laboratory assistance. We also acknowlege Glenn Almquist for some of the integrated light data. This research was supported by the Biological Oceanography Program of the National Science Foundation through Grant OCE 81-21881.

\section{LITERATURE CITED}

Ammerman, J. W., Fuhrman, J. A. Hagström, A., Azam, F (1984). Bacterioplankton growth in seawater: I. Growth kinetics and cellular characteristics in seawater cultures. Mar. Ecol. Prog. Ser. 18: 31-39

Bailey, C. A., Neihof, R. A., Tabor, P. S. (1983). Inhibitory effect of solar radiation on amino acid uptake in Chesapeake Bay bacteria. Appl. environ. Microbiol. 46: $44-49$

Burney, C. M. (1986). Bacterial utilization of total in situ dissolved carbohydrate in offshore waters. Limnol. Oceanogr. 31: 427-431

Burney, C. M., Johnson, K. M., Lavoie, D. M., Sieburth, J.MCN. (1979). Dissolved carbohydrate and microbial ATP in the North Atlantic: concentrations and interactions. Deep Sea Res. 26A: 1267-1290

Burney, C. M., Johnson, K. M., Sieburth, J.McN. (1981). Diel flux of dissolved carbohydrate in a salt marsh and a simulated estuarine ecosystem. Mar. Biol. 63: 175-187

Burney, C. M., Davis, P. G., Johnson, K. M., Sieburth, J.McN. 
(1982). Diel relationships of microbial trophic groups and in situ dissolved carbohydrate dynamics in the Caribbean Sea. Mar Biol. 67: 311-322

Calkins, J. (1975). Effects of real and simulated solar UV-B in a variety of aquatic microorganisms. CIAP (Climatic Impact Assessment Program) Monogr. 5: 5-33

Calkins, J., Thordardottir, T. (1980). The ecological significance of solar $U V$ radiation of aquatic organisms. Nature, Lond. 283: 563-566

Chamberlin, C. E., Mitchell, R. (1978). A decay model for enteric bacteria in natural waters. In: Mitchel, R. (ed.) Water pollution microbiology, Vol. 2. John Wiley and Sons, New York

Conrad, R., Seiler, W. (1982). Utilization of traces of carbon monoxide by aerobic oligotrophic microorganisms in ocean, lake and soil. Arch. Microbiol. 132: 41-46

Conrad, R., Seiler, W., Bunse, G., Giehl, H. (1982). Carbon monoxide in seawater (Atlantic Ocean). J. geophys. Res. 87: 8839-8852

Cynar, S. J., Estep, K. W., Sieburth, J.McN. (1985a). The detection and characterization of bacterial-sized protists in 'protist-free' filtrates and its potential impact on experimental marine ecology. Microb. Ecol. 11: 288-288

Cynar, F. J., Sieracki, M. E. Sieburth, J. McN. (1985b). Estimating plankton populations with the Apple II. Bioscience 35: 652-655

Davis, P. G., Caron, D. A., Johnson, P. W., Sieburth, J. McN. (1985). Phototrophic and apochlorotic components of picoplankton and nanoplankton in the North Atlantc: geographic, vertical, seasonal and diel distributions. Mar. Ecol. Prog. Ser. 21: 15-26

Dexter, S. C., Sullivan, J. D., Williams, J., Watson, S. W. (1975). Influence of substrate wettability on the attachment of marine bacteria to various surfaces. Appl. Microbiol. 30: 298-308

Eisenstark, A. (1971). Mutagenic and lethal effects of visible and near-ultraviolet light on bacterial cells. Adv. Genet. 16: $167-198$

Ferguson, R. L., Palumbo, A. V. (1979). Distribution of suspended bacteria in neritic waters south of Long Island during stratified conditions. Limnol. Oceanogr. 24: $697-705$

Ferguson, R. L., Buckley, E. N., Palumbo, A. V. (1984). Response of marine bacterioplankton to differential filtration and confinement. Appl. environ. Microbiol. 47: 49-55.

Fischer, B. (1984). Die Bakterien des Meeres nach den Untersuchungen der Plankton-Expedition unter gleichzeitiger Berücksichtigung einiger älterer und neuerer Untersuchungen. In: Hensen, $V$ (ed.) Ergebnisse der PlanktonExpedition der Humbolt-Stiftung, Vol. IV Lipsius and Tischer, Kiel

Fuhrman, J. A., McManus, G. (1984). Do bacteria-sized predators consume significant numbers of bacteria? Science 224: $1257-1260$

Fridovich, I. (1974). Superoxide dismutase. Adv. Enzymol. 41: 35-97

Fujioka, R. S., Hashimoto, H. H., Siwak, E. B., Young, R. H. F. (1981). Effect of sunlight on survival of indicator bacteria in seawater. Appl. environ. Microbiol. 41: 690-696

Gameson, A. L. H., Saxon, J. R. (1967). Field studies on effect of daylight on mortality of coliform bacteria. Wat. Res. 1: 279-295

Gates, F. L. (1928). Study of the bacterial action of ultraviolet light. J. gen. Physiol. 13: 231-260

Hobbie, J. E., Daley, R. J., Jasper, S. (1977). Use of Nuclepore filters for counting bacteria by fluorescence microscopy. Appl. environ. Microbiol. 33: 1225-1228
Hollaender, C. W (1943). Effect of long UV and short visible radiation $(3500-4900 \AA)$ on Escherichia coli. J. Bacteriol. 46: 531-541

Hooper, A. B., Terry, K. R. (1974). Photoinactivation of ammonia oxidation in Nitrosomonas. J. Bact. 119: 899-906

Horrigan, S. G., Carlucci, A. F., Williams, P. M. (1981). Light inhibition of nitrification in sea-surface films. J. mar. Res. 39: $557-565$

Jagger, J., Wise, J., Curtis, W., Stafford, R. S. (1964). Delay in growth and division induced by near ultraviolet radiation in Escherichia coli B and its role in photoprotection and liquid holding recovery. Photochem. Photobiol 3: 11-24

Jagger, J. (1975). Inhibition by sunlight of the growth of E. coli B/r. Photochem. Photobiol. 22: 67-70

Jerlov, N. G. (1950). UItraviolet radiation in the sea. Nature, Lond. 166: 111-112

Johnson, K. M., Davis, P. G., Sieburth, J. McN. (1983). Diel variation of $\mathrm{TCO}_{2}$ in the upper layer of oceanic waters reflects microbial composition, variation and possibly methane cycling. Mar. Biol. 77: 1-10

Jokiel, P. L, York, R. H. (1984). Importance of ultraviolet radiation in photoinhibition of microalgal growth. Limnol. Oceanogr. 29: 192-198

Kirchman, D. K., Ducklow, H. W., Mitchell, R. (1982). Estimates of bacterial growth from changes in uptake rates and biomass. Appl. environ. Microbiol. 44: $1296-1307$

Krambeck, C. (1984). Diurnal responses of microbial activity and biomass in aquatic ecosystems. In: Klug, M. J., Reddy, C. A., (ed.) Current perspectives in microbial ecology. Am. Soc. Microbiol., Washington, D. C.

Kubitschek, H. E., Doyle, R. J. (1981). Growth delay induced in Escherichia coli by near-ultraviolet radiation: relationship to membrane transport functions. Photochem. Photobiol. 33: 695-702

Lessard, E. J., Sieburth, J. McN. (1983). Survival of natural sewage populations of enteric bacteria in diffusion and batch chambers in the marine environment. Appl. environ. Microbiol. 45: 950-959

Li, W K. W., Dickie, P. M. (1985). Growth of bacteria in seawater filtered through $0.2 \mu \mathrm{m}$ Nuclepore membranes: implications for dilution experiments. Mar. Ecol. Prog Ser. 26: 245-252

Meyer-Reil, L. A., Bölter, M., Liebezeit, G., Schramm W. (1979). Short-term variations in microbiological and chemical parameters. Mar. Ecol. Prog. Ser. 1: 1-6

Mill, T., Hendry, D. G., Richardson, H. (1980). Free-radical oxidants in natural waters. Science 207: 886-887

Monod, J. (1949). The growth of bacterial cultures. Ann. Rev Microbiol. 3: 371-394

Moss, S. H., Smith, K. C. (1981). Membrane damage can be a significant factor in the inactivation of Escherichia coli by near-ultraviolet radiation. Photochem. Photobiol. 33 203-210

Müller-Neuglück, M., Engel, H. (1961). Photoinaktivierung von Nitrobacter winogradskyi Buch. Arch. Mikrobiol. 39: 130-138

N.A.S. (1979). Protection against depletion of stratospheric ozone by chlorofluorocarbons. National Academy of Sciences, Washington D. C.

Olsen, R. J. (1981). Differential photoinhibition of marine nitrifyng bacteria: a possible mechanism for the formation of the primary nitrite maximum. J. mar. Res. 39: $27-238$

Porter, K. G., Feig, Y. S. (1980). The use of DAPI for identifying and counting aquatic microflora. Limnol. Oceanogr. 25: $943-948$ 
Ramabhadran, T V., Jagger, J. (1975). Evidence against DNA as the target for $334 \mathrm{~nm}$-induced growth delay in Escherichia coli. Photochem. Photobiol. 21 227-233

Ramabhadran, T V., Jagger, J. (1976). Mechanism of growth delay induced in Escherichia coli by near ultraviolet radiation. Proc natn. Acad. Sci. U.S.A. 73: 59-63

Schmidt-Nielsen, S. (1901). Beitrag zur Biologie der marinen Bakterien. Biol. Zbl. 21 65-71

Sieburth, J. McN. (1964). Role of algae in controlling bacterial populations in estuarine waters. Symp. Pollut. mar. par Microorgan. Comm. int. Explor. sci. Mer. Medit., Monaco, p. $217-233$

Sieburth, J. McN. (1967). Seasonal selection of estuarine bacteria by water temperature. J. exp. mar. Biol. Ecol. 1: 98-121

Sieburth, J. McN. (1968a). Observations on bacteria planktonic in Narragansett, Rhode Island; a resumé. Bull. Misaki mar. biol. Inst. Kyoto University 12: 49-64

Sieburth, J. McN. (1968b). The influence of algal antibiosis on the ecology of marine microorganisms. In: Droop. M. R. Ferguson Wood E. J. (ed.) Advances in microbiology of the sea. Academic Press, New York, p. 63-94

Sieburth, J. McN., Pratt, D. M. (1962). Anticoliform acitvity of sea water associated with the termination of Skeletonema costatum blooms. Trans N. Y. Acad. Sci., Ser. II 24: 498-501

Sieburth, J. McN., Johnson, K. M., Burney, C. M., Lavoie, D. M. (1977). Estimation of insitu rates of heterotrophy using diurnal changes in dissolved organic matter and growth rates of picoplankton in diffusion culture. Helgoländer wiss. Meeresunters. 30: 565-574

Sieburth, J. McN., Johnson, P. W., Eberhardt, M. A., Sieracki, M. E. (1984). Methane oxidizing bacteria from the mixing layer of the Sargasso Sea and their photosensitivity. Abstr Ocean Sciences Meeting, EOS 64: 1054

Sieracki, M. E., Sieburth, J. McN. (1985). Factors controlling the periodic fluctuation in total planktonic bacterial populations in the upper ocean: comparison of nutrient, sunlight and predation effects. Mar. microb. Food Webs 1 $35-50$

Sieracki, M. E., Johnson, P. W., Sieburth, J. McN. (1985).
Detection, enumeration and sizing of aquatic bacteria by image-analyzed epifluorescence microscopy. Appl environ. Microbiol. 49: 799-810

Smith, K. C. (1977). Ultraviolet radiation effects on molecules and cells. In: Smith, K. C. (ed.) The science of photobiology. Plenum Press, New York, p. 113-142

Smith, R. C., Baker, K. S. (1979). Penetration of UV-B and biologically effective dose-rates in natural waters. Photochem. Photobiol. 29: 311-323

Straskrabova, V., Fuska, J. (1982). Diel changes in numbers and activities of bacterioplankton in a reservoir in relation to algal production. Limnol. Oceanogr. 27: 660-672

Thomson, B. E., Van Dyke, H., Worrest, R. C. (1980). Impact of UV-B (290-320 nm) upon estuarine bacteria. Oecologia (Berl.) 47: 56-60

Ward, B. B., Olson, R. J., Perry, M. J. (1981). Microbial nitrification rates in the primary nitrite maximum off southern California. Deep Sea Res. 29: 247-255

Watson, S. W., Novitsky, T. J., Quinby, H. L., Valois, F. W (1977). Determination of bacterial number and biomass in the marine environment. Appl. environ. Microbiol. 33: 940-946

Wilson, D. F., Swinnerton, J. W., Lamontagne, R. A. (1970) Production of carbon monoxide and gaseous hydrocarbons in seawater: relation to dissolved organic carbon. Science 168: $1577-1579$

Worrest, R. C., Van Dyke, H., Thomson, B. E. (1978). Impact of enhanced simulated solar ultraviolet radiation upon a marine community. Photochem. Photobiol. 27: 471-478

Zafiriou, O. C., Joussot-Dubien, J. Zepp, R. G., Zika, R. G (1984). Photochemistry of natural waters. Environ. Sci. Technol. 18: 358A-371A

Zika, R. G. (1981). Marine organic photochemistry. In: Duursma, E. K., Dawson, R. (ed.) Marine organic chemistry: evolution, composition, interactions and chemistry of organic matter in seawater. Elsevier Scientific Publ. Co., New York, p. 299-235

ZoBell, C. E., McEwen, G. F. (1935). The lethal action of sunlight upon bacteria in sea water. Biol. Bull. mar biol. Lab., Woods Hole 68: 93-106 